\title{
PLACES TO SIT FOR SENIOR CITIZENS LOCATED IN URBAN SPACE: WARSAW CITY AS A CASE STUDY
}

\author{
Maja Skibińska ${ }^{1 凶}$, Mariusz Wieczorek $^{2}$, Małgorzata Denis ${ }^{3}$ \\ ${ }^{1}$ Faculty of Civil and Environmental Engineering, Warsaw University of Life Sciences - SGGW, Warsaw \\ ${ }^{2}$ Faculty of Philosophy and Sociology, University of Warsaw, Warsaw \\ ${ }^{3}$ Faculty of Geodesy and Cartography, Warsaw University of Technology, Warsaw
}

\begin{abstract}
Benches are urban furniture which guarantee comfort for all users, which is important especially in the context of the needs of aging societies. Their location, number and construction are of great significance. The present paper is based on the results of a research projects concerning urban benches in Warsaw public space. The substantive scope of the study embraces identification of the current problems related to places to sit in urban areas as well as the needs of the elderly connected therewith. According to the research results benches should have a backrest or backrest and armrest, be placed at regular intervals in the vicinity of the place of residence and services. This paper is a contribution to the discussion on shaping public space that is comfortable for the seniors.
\end{abstract}

Key words: senior-friendly cities, pedestrian policy, public space, street furniture, urban bench, urban planning

\section{INTRODUCTION}

The aging of societies is a challenge for both local and global policies and economies. Seniors' mobility is conditional upon a great variety of factors including, most of all, health condition, physical environment as well as the possibility of receiving support. The paper in question is focused on the local context of this phenomenon - confrontation of the existing infrastructural and architectural solutions with the social needs and expectations of the elderly. Senior citizens constitute a very diverse social group whose needs and possibilities of their fulfilment change as their age advances. A common denominator for households run by seniors is the need to maintain the greatest possible independence and psychophysical fitness, which is determined mainly by the fact of living alone. Creating comfortable places to sit in public spaces provides conditions for maintaining as well as establishing social contacts and spending time with other people outdoors, which is beneficial for the mental well-being of older people. The main objective of the study was to determine users' needs regarding the functioning, location, quantity and construction of benches in public urban space on the basis of interviews with the elderly (60+) (Prezydent m.st. Warszawy, 2013).

The application purpose is to formulate recommendations regarding places to sit for seniors located in transit areas. 


\section{THE CURRENT STATE OF RESEARCH}

One of the features of age-friendly cities was the availability of seats in public space. This results from the difficulty in going for a walk, even in the immediate vicinity of the house, which is faced by the elderly if they have nowhere to rest (WHO, 2007; King, 2008; Prezydent m.st. Warszawy, 2016; Lotvonen, Kyngäs, Koistinen, Bloigu \& Elo, 2017). In publication Miasto dla wszystkich... (2015) the idea of a 'short-distance' city (a compact city) is highlighted. The motto "seniority is a space expert" directly emphasises the principles of universal spatial design by adapting it also to the needs of people with limited mobility or disabilities (Trakul-Masłowska, 2015). The availability of space affects person's willingness to leave the house, which results in the improvement of mental and physical condition of users (WHO, 2007; Clarke, Ailshire, \& Lantz, 2009; Clarke \& Nieuwenhuijsen, 2009; Bjornsdottir, Arnadottir \& Halldorsdottir, 2011; I'DGO, 2012; Bynon \& Rishbeth, 2015; Lotvonen et al., 2017). The possibility of sitting in public space favours integration process (Gehl, 1987; Balfour \& Kaplan, 2002; Lotvonen et al., 2017). In the case of transit areas locating benches at uniform distances is of utmost importance since the predictability of their location ensures effective pedestrian mobility (Gehl, 1987; Cunningham, Michael, Farquhar \& Lapidus, 2005; Hovbrandt, Stålh \& Iwarsson, 2007; Main \& Hannah, 2010; I'DGO, 2012; Newton, 2015; Olszak, Sadowska, Skibińska \& Wieczorek, 2018). According to the research carried out by I'DGO (2012), $95 \%$ of seniors would appreciate the opportunity to rest on a bench on their way to a park. As far as transit areas are concerned, the most typical feature is the location of single seat benches, whereas arrangement of several benches next to one another (sociopetal seating), where possible, favours establishment of social relations (Gehl, 1987; Main \& Hannah, 2010; Newton, 2015; Olszak, Sadowska, Skibińska \& Wieczorek, 2018). The entire city should be "fit to sit", which may be achieved by providing primary seating (benches and chairs) as well as secondary seating (other forms, e.g. steps, low walls) (Gehl, 1987). The availability and variety of seats adjusted to the variegated needs of public space users are significant (Jacobs, 1971; Whyte, 1980; Mooney \& Luymes, 1999; Madden, 2001; Main \& Hannah, 2010;
Bynon \& Rishbeth, 2015). Bench condition (not damaged and cleanliness) is also important (Michael, Keast, Chaudhury, Day, Mahmood \& Sarte, 2009; Cunningham et al., 2005). In transit areas recommended is distance of approximately $100 \mathrm{~m}$ between seats (benches to rest) located in the area of streets, with greater density of places to sit in the case of hilly terrains (Gehl, 1987; Lee \& Moudon, 2006; Bjornsdottir et al., 2011; I'DGO, 2012; Newton, 2015). In design study report (Mooney \& Luymes, 1999) emphasised the need to provide benches and other seats every $40-50 \mathrm{~m}$ intervals. Benches for the elderly should be comfortable: a well contoured seat and backrest, appropriate height and availability of armrests - facilitate standing up from a bench (Madden, 2001; Michael et al., 2009; Main \& Hannah, 2010; I'DGO, 2012; Barron, 2015; Bynon \& Rishbeth, 2015; Newton, 2015; Trakul-Masłowska, 2015). When planning the number, location and forms of seats, it is necessary to consult public space users, including seniors, so as to satisfy their needs as much as possible (Main \& Hannah, 2010; Barron, 2015; Klaman, 2015; Skibińska $\&$ Wieczorek, 2018). In the interviews conducted by the I'DGO team (2012), you can also notice the resignation and reconciliation of the majority of respondents with the "every solution is good" approach, that is, we use all forms suitable for sitting, even if they were not functionally designed in this way, e.g. small wall or rubbish bin. The principal goal Development of Pedestrian Traffic in Warsaw (2016) is "Enhancing the role and quality of pedestrian traffic considering the needs of all groups of users, including persons with reduced mobility". From the perspective of senior citizens in Warsaw, a guidelines for locating benches considering the needs of pedestrians during street renovations are important.

\section{MATERIAL AND METHODS}

The main research question was: how to best adjust seating places to the needs of seniors in Warsaw? Based on previous observations and desk research a decision on the location was made with respect to the socio-demographic profile of residents. The key features that were taken into consideration in the selection of the location embrace large concentration of persons aged $60+$, as well as close access to local services (within a distance of $500 \mathrm{~m}$ ). In the case of 
Warsaw, the largest proportion of people at retirement age is observed in seven districts: Bielany, Mokotów, Ochota, Śródmieście, Targówek, Wola and Żoliborz (Fig. 1). The present study was carried out in Bielany, Ochota and Mokotów districts (Figs. 2, 3). Seventy four respondents aged from 62 to 94 of which 51 were women, 23 men participated in the study. Individual interviews were conducted with all of them, in which we focused on various aspects of using the benches described in the further part of the article. Most respondents went with us for a research walk during which they indicated their favourite routes and places of rest. People who were unable to make long trips were asked for a story during which we made a route and mark with approximate resting points on map. Then, the researchers themselves went to places described by the respondents to make an inventory of the benches encountered on the route (photo and description). We have prepared maps containing all data collected from the respondents in the area. They were analysed during which we looked for the relationship between the location of the benches and the marked communication routes. We have also focused on white spots forcing respondents to various adaptation strate- gies that respond to shortages of seats in the immediate vicinity. These places are also most often indicated as potential abbreviations and a great convenience in the implementation of everyday tasks, if benches are added there.

The following research methods were applied for the purposes of performance of the present study:

- desk research - searching for information enabling the choice of the optimal location for the study including seniors as the main users of public space;

- on-site visit and observation - recognition of the functional and spatial context of the surroundings and the area of the study. Getting to know the manner in which a given place functions, identifying forms intended for sitting (Table 1). The researchers marked the seats available in the study area on one map, whereas individual routes along which the researchers had walks with the respondents were marked on other maps;

- individual depth interview - performed in the area of the study based on an interview questionnaire and a map of the area to mark the routes used by the respondents and to indicate the need for resting places.
Fig. 1. Population at post-working age given as a percentage of the total population of the district in 2015 (source:https://www.bankier.pl/i/n/201502/kJv9yWY5hRvw_m3dc7c720.png, access 06.12.2018)

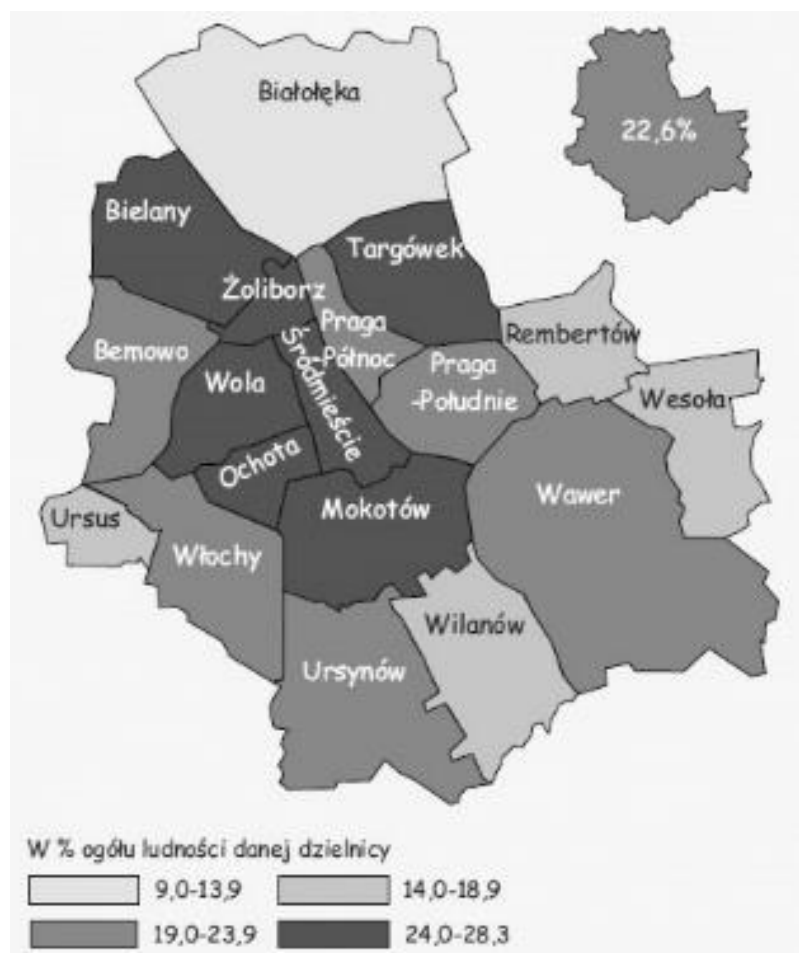




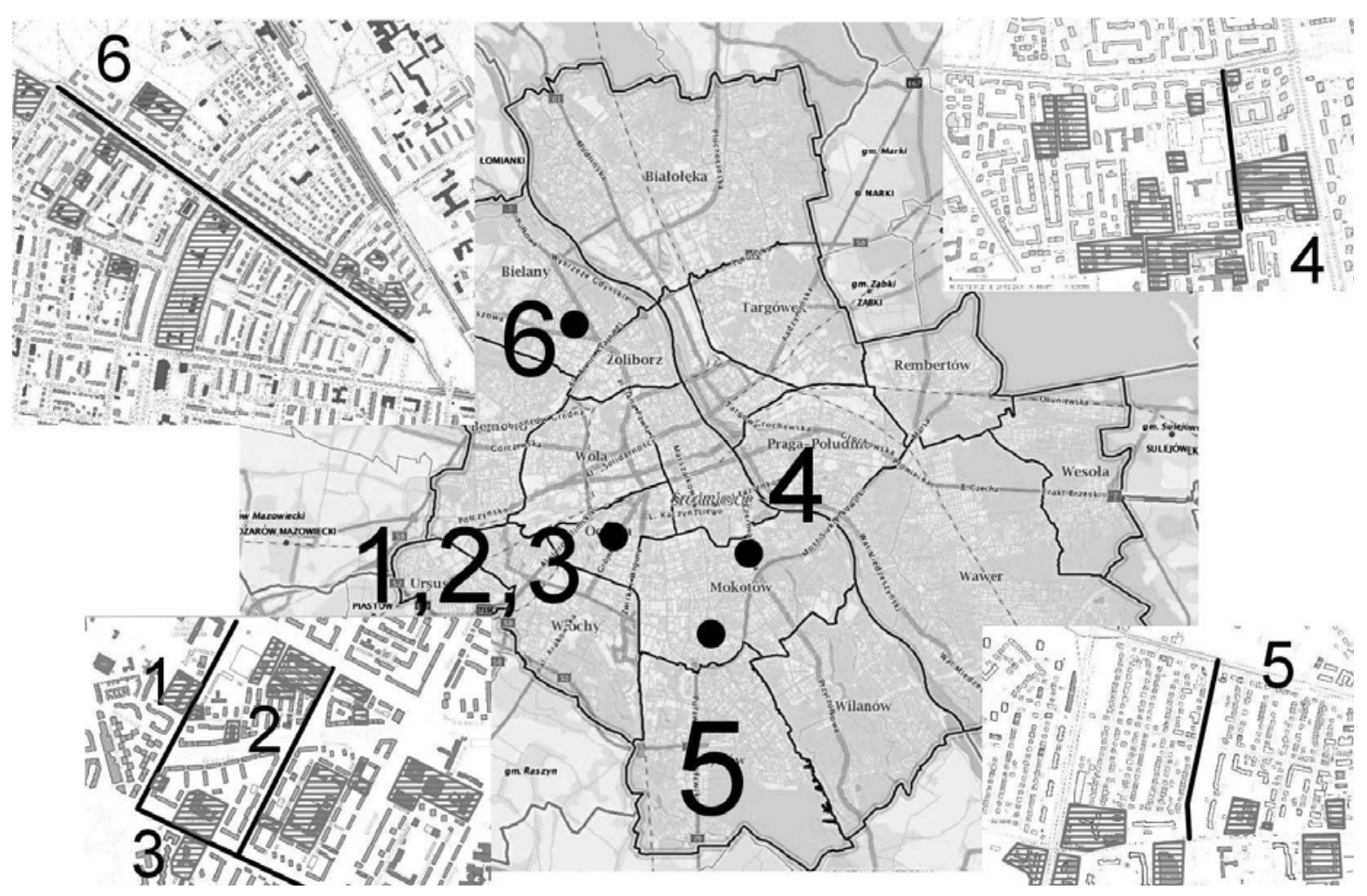

Fig. 2. Distribution of research points on the map of Warsaw: 1 - Szczęśliwicka street; 2 - Białobrzeska street; 3 - Dickensa street; 4 - Czerska street; 5 - Rolna street; 6 - Kasprowicza street (own elaboration)
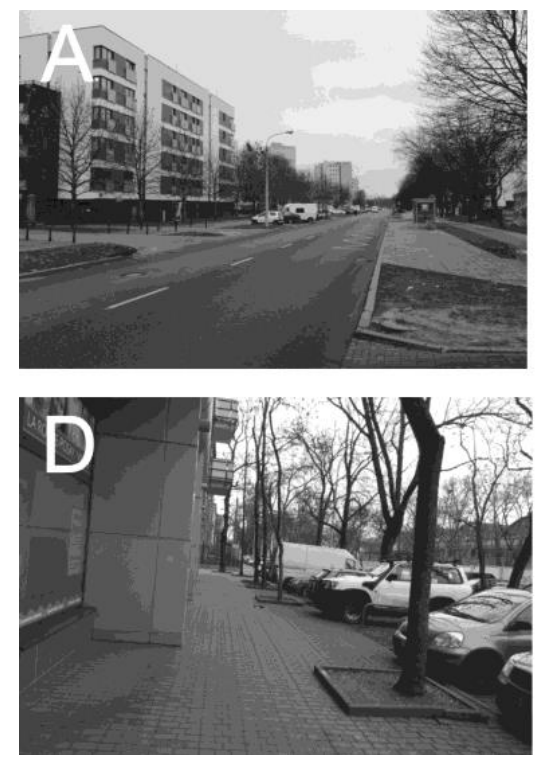
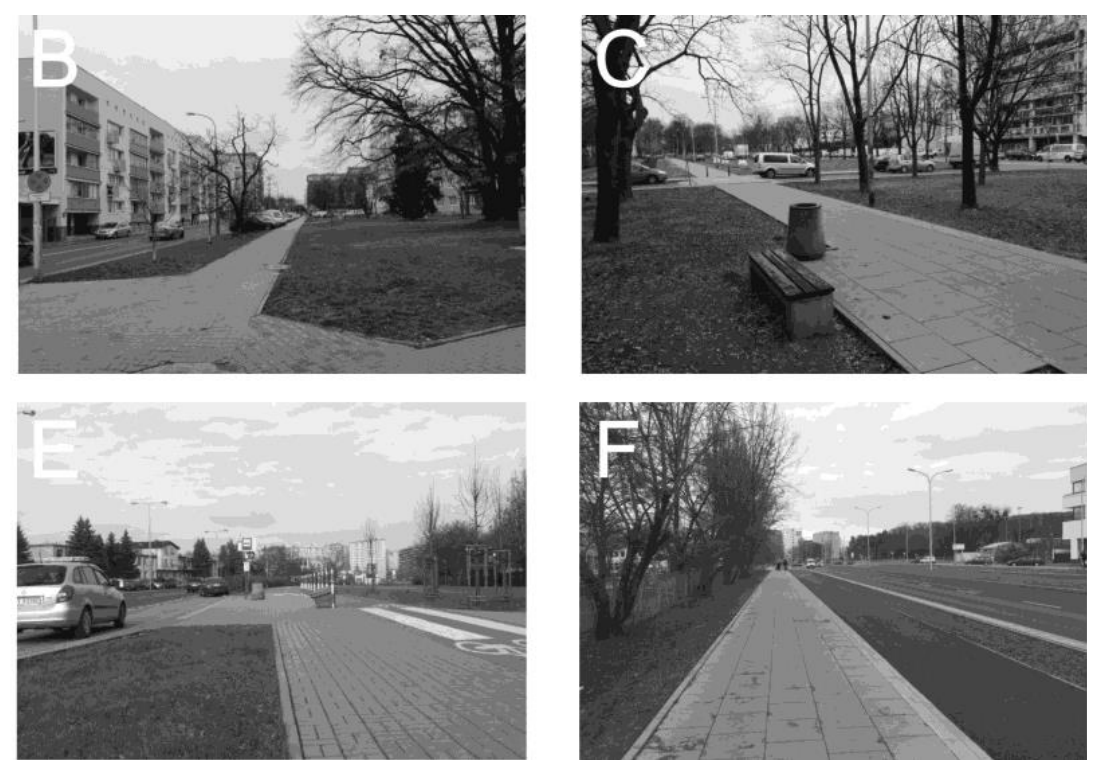

Fig. 3. Research points: A - Szczęśliwicka street, B - Białobrzeska street; C - Dickensa street; D - Czerska street; E - Rolna street; F - Kasprowicza street (own elaboration) 
Skibińska, M., Wieczorek, M., Denis, M. (2019). Places to sit for senior citizens located in urban space: Warsaw city as a case study. Acta Sci. Pol. Architectura, 18 (3), 67-77. doi: 10.22630/ASPA.2019.18.3.36

Table 1. Specification and data collection methodologies of case studies (own elaboration)

\begin{tabular}{|c|c|c|c|c|c|c|c|c|c|}
\hline \multirow[b]{3}{*}{ District } & \multirow[b]{3}{*}{ Case study } & \multicolumn{6}{|c|}{ Materials } & \multirow{2}{*}{\multicolumn{2}{|c|}{ Interviews }} \\
\hline & & \multicolumn{2}{|c|}{ neighbourhood } & \multicolumn{4}{|c|}{ case studies } & & \\
\hline & & 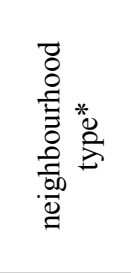 & 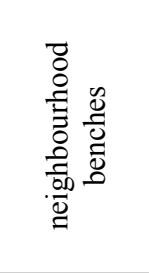 & 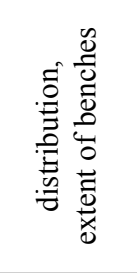 & 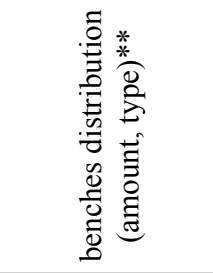 & 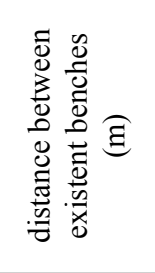 & 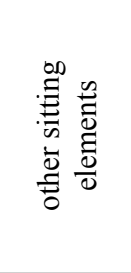 & 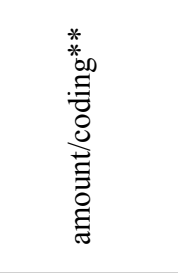 & $\stackrel{\vec{J}}{\stackrel{\Delta}{2}}$ \\
\hline Ochota & $\begin{array}{l}\text { Szczęśliwicka st. } \\
\text { (fragment } \\
\text { ca. } 650 \mathrm{~m} \text { ) }\end{array}$ & $\mathrm{s}, \mathrm{p}, \mathrm{g}$ & yes & $\begin{array}{c}\text { street } \\
\text { fragment }\end{array}$ & $\begin{array}{c}4 \text { wob, } \\
4 \text { bbs }\end{array}$ & 40 & no & 11/OS 1-11 & 2016 \\
\hline Ochota & $\begin{array}{l}\text { Białobrzeska st. } \\
\text { (fragment } \\
\text { ca. } 700 \mathrm{~m} \text { ) }\end{array}$ & $\begin{array}{l}\mathrm{p}, \mathrm{d}, \mathrm{g} \\
\text { os }\end{array}$ & yes & $\begin{array}{c}\text { street } \\
\text { fragment }\end{array}$ & $2 \mathrm{bbs}$ & no & no & 12/OB 1-12 & 2017 \\
\hline Ochota & $\begin{array}{l}\text { Dickensa st. } \\
\text { (fragment } \\
\text { ca. } 600 \mathrm{~m} \text { ) }\end{array}$ & fh, $p, d$ & yes & $\begin{array}{c}\text { street } \\
\text { fragment }\end{array}$ & 4 wob & $\begin{array}{c}40-60 \\
\text { (irregular) }\end{array}$ & no & $8 / \mathrm{OK} 1-8$ & 2017 \\
\hline Mokotów & $\begin{array}{l}\text { Czerska st. } \\
\text { (whole } \\
\text { ca. } 450 \mathrm{~m} \text { ) }\end{array}$ & $\begin{array}{l}\text { s, gs, os, } \\
\text { d, c }\end{array}$ & $\begin{array}{c}\text { no } \\
\text { (only at } \\
\text { bus stops) }\end{array}$ & no & no & no & $\begin{array}{c}\text { low } \\
\text { concrate } \\
\text { wall }\end{array}$ & 6/MC 1-6 & 2016 \\
\hline Mokotów & $\begin{array}{l}\text { Rolna st. } \\
\text { (whole } \\
\text { ca. } 450 \mathrm{~m} \text { ) }\end{array}$ & $\begin{array}{l}\mathrm{sc}, \mathrm{b}, \mathrm{g} \\
\mathrm{os}, \mathrm{c} \\
\mathrm{ms}\end{array}$ & $\begin{array}{c}\text { no } \\
\text { (only at } \\
\text { bus stops) }\end{array}$ & no & no & no & no & 15/MR 1-15 & 2018 \\
\hline Bielany & $\begin{array}{l}\text { Kasprowicza st. } \\
\text { (fragment } \\
\text { ca. } 1600 \mathrm{~m} \text { ) }\end{array}$ & $\begin{array}{l}\mathrm{s}, \mathrm{g}, \mathrm{d}, \\
\mathrm{os}, \mathrm{ms}\end{array}$ & yes & $\begin{array}{c}\text { street } \\
\text { fragment }\end{array}$ & $\begin{array}{l}6 \mathrm{bbs}, 4 \text { wob } \\
\text { (near metro } \\
\text { stations), } 35 \mathrm{wb}\end{array}$ & $40-70$ & $\begin{array}{c}\text { low } \\
\text { concrate } \\
\text { wall }\end{array}$ & 22/BK 1-22 & 2018 \\
\hline
\end{tabular}

* p - park; s - supermarket; sc - shopping centre; fh - fair halls; $\mathrm{g}$ - grocery store; $\mathrm{b}$ - bakery; os - other shops; $\mathrm{c}$ - clinic; $\mathrm{d}$ - drugstore; ms - metro station.

** wob - bench without backrest; wb - bench with backrest; bbs - bench at bus stop.

*** coding - the respondent's codes are a combination of the first letters district-street and the sequential order number. For example the code [OB-4] means that the given quote comes from the interview conducted with the fourth respondent from (Ochota district) Białobrzeska street [Ochota-Białobrzeska-4th respondent].

\section{RESULTS}

Research was conducted in six locations in three districts with the highest concentration of elderly people. Table 2 provides an overview of the information obtained from the respondents regarding their needs grouped into three main aspects and taking into account significant additional issues having a significant impact on the location of benches.

Concentration. The conducted interviews (61 out of 74) was dominated by one issue: "too few bench- es" in the immediate area. There is a very clear sign of some resignation and lack of faith in the change of the current situation of the deficit of benches. When asked about the preferred construction of a bench, eight respondents replied that "no matter what they [benches] are like, it is important that they [any] are available at all".

Location. In the case of streets where respondents recommended the addition of extra benches, the target distance between them was 25-100 m and depended, among others, on the current way of spatial develop- 
Table 2. Synthesis of study results (own elaboration)

\begin{tabular}{|c|c|c|c|c|c|c|c|c|}
\hline \multirow[b]{3}{*}{ District } & \multirow[b]{3}{*}{ Case study } & \multicolumn{7}{|c|}{ Needs of respondents concerning benches } \\
\hline & & \multicolumn{2}{|c|}{ concentration } & \multicolumn{3}{|c|}{ location } & construction & \multirow[b]{2}{*}{ 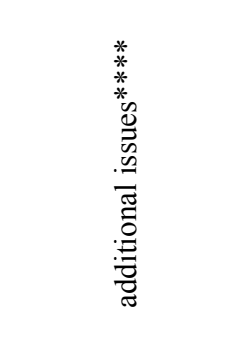 } \\
\hline & & 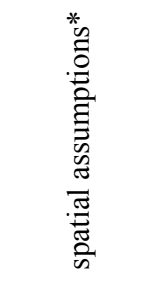 & 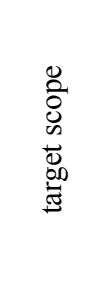 & 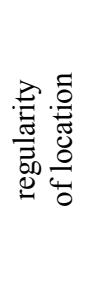 & 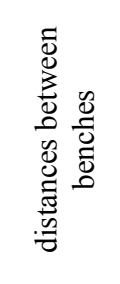 & 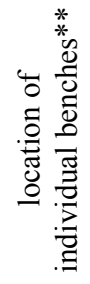 & 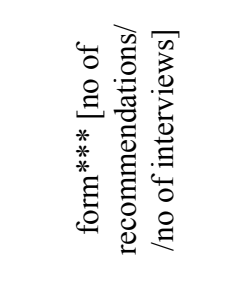 & \\
\hline Ochota & $\begin{array}{l}\text { Szczęśliwicka st. } \\
\text { (fragment) }\end{array}$ & $\begin{array}{l}\text { additional } \\
\text { seats }\end{array}$ & $\begin{array}{l}\text { entire } \\
\text { street }\end{array}$ & no & $80-100$ & $\mathrm{sb}$ & $\begin{array}{c}\text { wob }[1 / 11], \\
\text { wb }[8 / 11], \\
\text { wbaa }[5 / 11]\end{array}$ & alternative route \\
\hline Ochota & $\begin{array}{l}\text { Białobrzeska st. } \\
\text { (fragment) }\end{array}$ & new & $\begin{array}{l}\text { entire } \\
\text { street }\end{array}$ & yes & $40-70$ & $\begin{array}{l}\mathrm{sb}, \\
\text { tbs }\end{array}$ & $\begin{array}{c}\text { wob }[0 / 12], \\
\text { wb }[12 / 12], \text { wbaa } \\
{[10 / 12]}\end{array}$ & - \\
\hline Ochota & $\begin{array}{l}\text { Dickensa st. } \\
\text { (fragment) }\end{array}$ & $\begin{array}{l}\text { additional } \\
\text { seats }\end{array}$ & $\begin{array}{l}\text { entire } \\
\text { street }\end{array}$ & yes & $25-35$ & $\mathrm{sb}$ & $\begin{array}{c}\text { wob }[1 / 8], \\
\text { wb }[8 / 8], \\
\text { wbaa }[5 / 8]\end{array}$ & $\begin{array}{c}\text { alternative route, } \\
\text { potential drinking } \\
\text { bouts }\end{array}$ \\
\hline Mokotów & Czerska st. & new & $\begin{array}{l}\text { frag- } \\
\text { ment }\end{array}$ & yes & $60-80$ & tbs & $\begin{array}{c}\text { wob }[1 / 6], \\
\text { wb }[6 / 6], \\
\text { wbaa }[6 / 6]\end{array}$ & $\begin{array}{c}\text { potential drinking } \\
\text { bouts, alternative } \\
\text { seats }\end{array}$ \\
\hline Mokotów & Rolna st. & new & $\begin{array}{l}\text { entire } \\
\text { street }\end{array}$ & no & 60 & $\begin{array}{l}\mathrm{sb}, \\
\text { tbs }\end{array}$ & $\begin{array}{c}\text { wob }[2 / 15], \\
\text { wb }[14 / 15], \text { wbaa } \\
{[12 / 15]}\end{array}$ & indifference \\
\hline Bielany & $\begin{array}{l}\text { Kasprowicza st. } \\
\text { (fragment) }\end{array}$ & $\begin{array}{l}\text { additional } \\
\text { seats }\end{array}$ & $\begin{array}{l}\text { entire } \\
\text { street }\end{array}$ & yes & $40-70$ & $\begin{array}{l}\mathrm{sb}, \\
\text { ao }\end{array}$ & $\begin{array}{c}\text { wob }[3 / 22], \\
\text { wb }[22 / 22], \\
\text { wbaa }[19 / 22]\end{array}$ & $\begin{array}{c}\text { potential drinking } \\
\text { bouts, alternative } \\
\text { seats }\end{array}$ \\
\hline
\end{tabular}

* additional seats - providing additional seats in places where there is a lack of benches - white spots on research maps; new - providing new benches.

** sb - single bench; tbs - two benches side by side; ao - alternately and opposite one another.

*** wob - bench without backrest; wb - bench with backrest; wbaa - bench with backrest and armrests.

**** alternative route - park as an alternative route; potential drinking bouts - benches as a place for potential drinking bouts; alternative seats - searching for alternative seats; indifference - indifference to the issue of benches.

ment (the longer distance concerned the streets where location of benches is impossible due to the narrow pavement). Whereas, in the streets without benches, the desirable distance was 40-80 m (Fig. 4). Alternative strategies developed by one in four seniors when faced with scarcity or lack of benches along streets prove the importance of the availability of seats. In such spaces the elderly apply different adaptation strategies, mostly resulting from locomotor impairments of different individuals. The most popular strategy consists in going shopping with a specially designed trolley on two wheels with an aim not only to relieve painful hands from heavy shopping bags and facilitate walking (including stairs), but also to serve as a mobile seat and support. The second strategy is to take old newspapers so as to be able to have a rest anywhere - on a small wall, windowsill, rubbish bin, tool box - and be protected against cold and staining of clothing. The female respondent [OS-8], aged 84, who gets tired standing in one point, tries to walk slowly in 


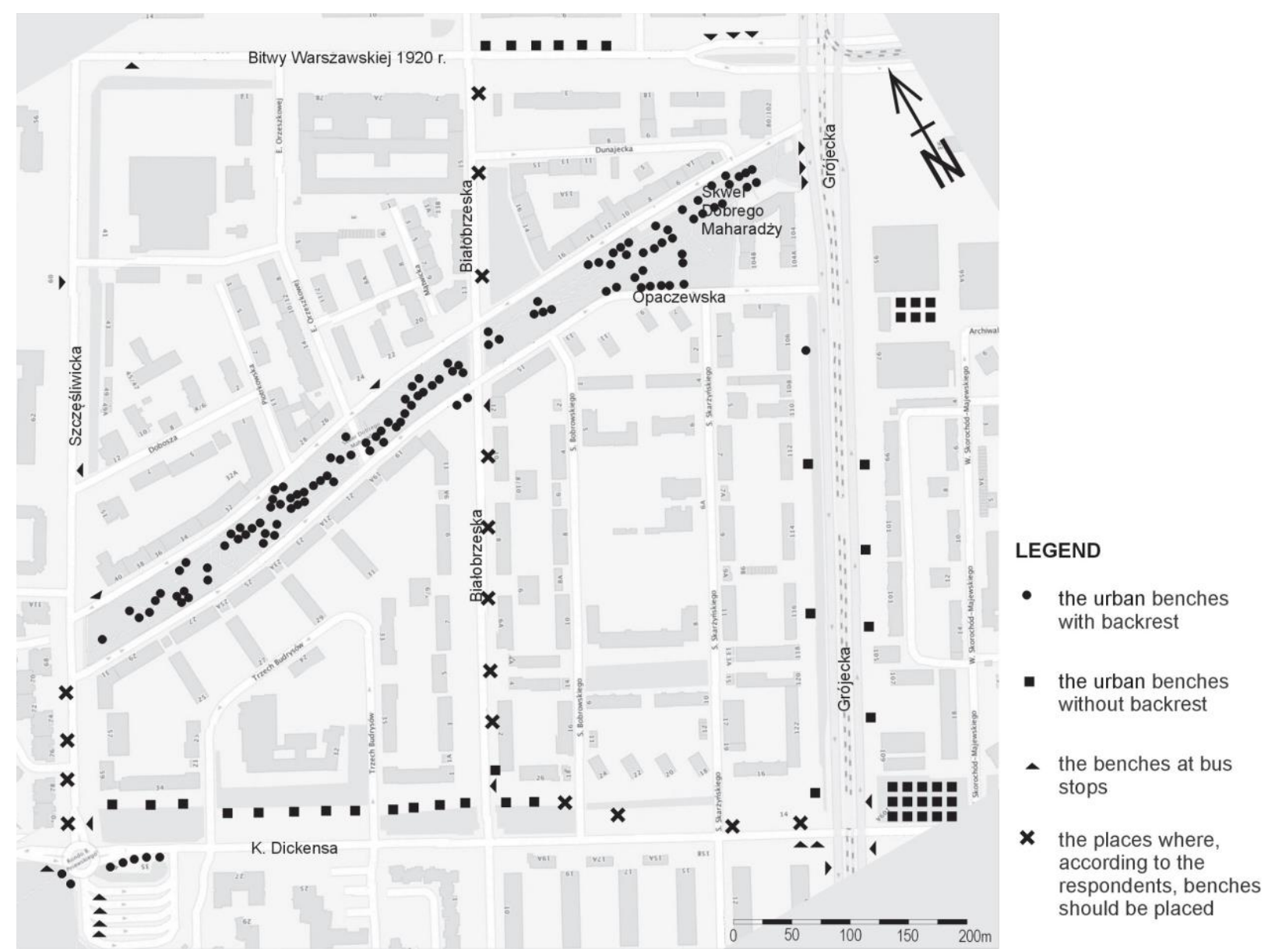

Fig. 4. Map of the Szczęśliwicka, Dickensa and Białobrzeska street and the context of the surrounding (prepared by: P. Olszak on the basis of an on-site visit and interviews with the respondents, graphic design by M. Skibińska)

place if there are no seats on the route chosen by her. The male respondent with knee disturbances [OB-4], aged 72 , reported sitting down and standing up as the biggest problem therefore he does not use benches that are not high enough. Other strategies, not connected with walking, embrace travelling short distances in winter by public transport (1-2 bus stops) or using a taxi for fear of falling, even when a distance does not exceed $200 \mathrm{~m}$. "There can never be too many benches! It doesn't matter what benches are like - what matters is regular distances between them" [BK-19], "It's important that benches are placed at regular distances" [OB-3]. "Benches should be visible" [OS-5].

Construction. Warsaw seniors expect (comfortable) backrest, being equipped with side armrests and a slightly higher seat, to make "standing up easier" [OB-11]. Respondent concluded that "Benches should be profiled, as they used to be in the past; and even now the old profiled benches allow pedestrians to sit down and lean back comfortably. And this is adapted more or less to the anatomy of the human body. However, more and more often benches lack backrest, whereas those which are equipped with it usually constitute a simple seat and simple backrest" [OD-11]. Majority of the respondents mentioned a bench with a backrest (70 out of 74) or with a backrest and armrests (57 out of 74) as the desirable solution. The solution with supports was backed up by the limited sitting area on a bench: "less space to sit" [MC-1], "ilf I have to sit down, I will be forced to sit close to the person who is 
already sitting there" [OK-3], "it will be more difficult to fit on a bench, e.g. to for three people to sit and put a bag on it" [BK-14]. The second argument proposed by the respondents was vandalism: "this is the first thing that can be removed" [MC-6], "the construction will be fragile, so it will certainly be destroyed" [BK-3]. Four out of five respondents indicated that they avoided benches without backrest because "In order to stand up from a seat like this without support I will have to 'move up and down' many times. And if I lean too much, I may fall over, that's why I avoid such seats" [OB-12]. In the case of benches without armrests, the elderly tend to sit on their edges, which is caused by the possibility of using their own arms and resting their back thereon to have support when standing up and sitting down on a bench.

Additional issues. In Ochota district the greatest density of benches with backrest and armrests and regular distances between them was observed on Dobrego Maharadży square (Fig. 4), as a result this route is willingly chosen by seniors during the warm months since then social life on benches is blooming, and "you can always meet someone you know" [OB-4].

The respondents emphasised the key role of benches in their everyday life as well as their insufficient number in terms of the onerous behaviour of people who consume alcohol there. One of the residents [OD-5] proposed a division into "good" - comfortable benches used by "non-threatening" seniors and mothers with children, where a large amount of transit traffic discourages people from consuming alcohol there, and "bad" benches - located in areas where traffic is lower, away from main streets, thereby being conducive to the gathering of larger groups of people and staying for the night by the homeless.

We also identified a group of seniors denying the use of benches - approximately one in 12. Most often these are people in good general health and physical condition. Although they do not make use of the surrounding space, they frequently refer to the needs of other space users with great empathy. "I do not use benches, but when I go for a walk with my mother who is limping, benches prove to be invaluable" [BK-21]. "I do not need to rest, but I watch my neighbours who use a walking stick or need to stop and put their shopping bags there" [OB-8].

\section{DISCUSSION}

The needs of the respondents identified in the course of the conducted interviews were to a large extent compatible with the good practices concerning benches for seniors referred to in relevant literature. Elderly people expect comfortable benches located at regular distances on popular pedestrian routes, and whose construction is adapted to their needs. The influence on the mental and social well-being of the study group was also confirmed.

Concentration. The study subjects deemed the existence of (comfortable) benches as the main reason for leaving the house to fulfil the need for movement. In the long run, all this translates into improved physical and mental comfort of the users of this space. The respondents noticed limitations determined by the manner of street development (e.g. Czerska and Rolna street), indicating only a part as fit for location of benches. On the basis of the guidelines concerning the location of new benches, concentration of benches in all study areas desired by the respondents as well as the optimum distance between benches within the transit spaces may be determined.

Location. In transit areas benches positioning proved to be a decisive factor in the selection of pedestrian routes by the elderly. The conducted studies confirmed the thesis presented in the literature: the arrangement of benches essentially affects the choice of a pedestrian route by an elderly person. The respondents unanimously emphasised the importance of regular distances between benches, continuity that ensures predictability in the choice of a route, thus providing mental comfort.

The results of research regarding the expected distances between benches were smaller than the distance of $100 \mathrm{~m}$ (Gehl, 1987). The distances between the benches indicated by respondent were similar to 40-50 m (Mooney \& Luymes, 1999) or distances less than $100 \mathrm{~m}$ indicated in the case of hilly terrains (Gehl, 1987; Lee \& Moudon, 2006; Bjornsdottir et al., 2011; I'DGO, 2012; Newton, 2015).

In transit areas, the most desirable types of benches were single benches. However, the example of Dobrego Maharadży square in Ochota together with the opinions of the elderly from Białobrzeska, Dickensa, Rolna 
and Kasprowicz street also showed that locating two benches opposite each other to facilitate unrestrained talks among their users was valued by the respondents as well (double seat benches - two benches next to each other as well as opposite and alternately). What is more, many respondents stressed the importance of arranging benches in a way to provide their users with a choice of using either a single seat bench or a group of benches favouring social interaction. This was in line with the data found in relevant literature.

Construction. Eight people recommended a bench without a backrest as a type worth locating at a street. According to the respondents, they are uncomfortable and usually seniors who live in areas where benches are not equipped with backrests, such as Dickensa street, use them mainly as places to put their shopping bags. In such areas, any object that is high enough may become a place to sit. Due to the fact that only a small percentage of respondents recommended benches without a backrest, these were not mentioned in the recommendations concerning benches for seniors as well as in the available literature. Deficits of benches force the elderly to choose the shortest possible pedestrian routes and apply substitute strategies. This is consistent with the results of the study conducted by the I'DGO team (2012) - "every solution is favourable", meaning that people use any forms that one can sit on, even if they are not functionally designed for this purpose. The long-term shortage of places to sit may have decreased the current level of expectations of the study group of Warsaw seniors who claimed that the existence of "any place to sit" is more important than the suitable construction of a bench. The issue in question was not referred to in 200 interviews carried out within the I'DGO project (2012).

Additional issues. So far two issues have not been discussed in the available literature. In contrast to the research conducted within the I'DGO project (2012), the elderly in Warsaw showed much concern about the issue of locating benches in public space in close proximity to residential premises. In the case of 41 out of 74 respondents, the fear of nuisance resulting from bustling nightlife on benches was greater than the need to care about their own comfort. Second interesting issue that was identified in the present study concerned active seniors. These are individuals for whom the use of benches equals physical weakness, disability, poor health condition and stereotypical approach to an elderly person. These are people who are active during walks and treat them as a form of sport. When asked about the use of benches, such persons may feel offended since they treat their use as a sign of weakness. They do not want to join the rank of the "typical" senior - a person at an advanced aged, ill, needing help and rest every dozen or several dozen meters.

\section{CONCLUSIONS AND RECOMMENDATIONS}

Concentration. In the case of transit areas, benches should be provided along with alternative forms of places to sit so as to enable rest or laying down your bags during walking. Places to sit ought to be situated on everyday routes used by seniors to reach the market, shops, pharmacies, clinics, libraries, park, bus stop etc. Designating such places together with the concerned users of such routes by means of e.g. social consultations is recommended.

Location. Locating places to sit, which encourage integration and spending time together, within short distance from places of residence as well as in areas used by the elderly (shops, health care centres, libraries, etc.). Almost all senior citizens find it important to evenly arrange benches in transit areas. Non-beneficial also indicated that for people of a similar age, but in a worse health condition, benches may be useful. After applying the results of the research to the terrain maps, we made calculations from which it follows that the optimum distances between benches range from 40 to $80 \mathrm{~m}$. If possible, the manner in which benches are arranged should provide the opportunity to choose to sit on a single seat bench or a bench that enables social interaction (double seat benches, located opposite one other or L-shaped).

Construction. Constructing a bench in a way providing comfort to seniors by using profiled backrest a seat and armrests. In order to improve the quality of life of the elderly, it is also worth providing alternative forms of seats where seniors could rest or put on their bags.

Additional issues. Any and all decisions regarding the location and form of benches need to be made together with seniors. 
The conducted research showed that the needs expressed by the elderly were divergent from the current policy of the city - namely location of few single seat benches and the use of forms without a backrest in transit areas. Providing new seats in a participatory manner, thereby engaging the local community, including seniors, in the decision-making process concerning urban benches proves to be of utmost value.

\section{REFERENCES}

Balfour, J. \& Kaplan, G. (2002). Neighborhood environment and loss of physical function in older adults: Evidence from the Alameda County Study. American Journal of Epidemiology, 155 (6), 507-515.

Barron, A. (2015). Age-Friendly Seating \& Sense of Place. Retrieved from: https://secure.manchester.gov.uk/downloads/download/6373/age-friendly_seating_and_sense of_place [accessed 05.12.2018].

Bjornsdottir, G., Arnadottir, S. \& Halldorsdottir, S. (2011). Facilitators of and barriers to physical activity in retirement communities: Experiences of older women in urban areas. Physical Therapy, 92 (4), 551-561. doi: 10.2522/ptj.20110149

Bynon, R. \& Rishbeth, C. (2015). Benches for everyone. Solitude in public, sociability for free. The Young Foundation. Retrieved from: https://youngfoundation.org/ wp-content/uploads/2015/11/The-Bench-Project_single-pages.pdf [accessed 16.11.2018].

Clarke, P. \& Nieuwenhuijsen, E. R. (2009). Environment for the healthy ageing: A critical review. Maturitas, 64, 14-19. doi: 10.1016/j.maturitas.2009.07.011

Clarke, P., Ailshire, J. A. \& Lantz, P. (2009). Urban built environments and trajectories of mobility disability: Findings from a national sample of community-dwelling American adults (1986-2001). Social Science \& Medicine, 69 (6), 964-970.

Cunningham, G. O., Michael, Y. L., Farquhar, S. A. \& Lapidus, J. (2005). Developing a Reliable Senior Walking Environmental Assessment Tool. American Journal of Preventive Medicine, 29 (3), 215-217.

Gehl, J. (1987). Life Between Buildings: Using Public Space. Washington-Covelo-London: Island Press.

Hovbrandt, P., Stålh, A. \& Iwarsson, S. (2007). Very old people's use of the pedestrian environment: functional limitations, frequency of activity and environmental demands. European Journal of Ageing, 4, 201-211. doi: 10.1007/s10433-007-0064-2
I'DGO (2012). Design Guides 001 Seating. Retrieved from: http://www.idgo.ac.uk/design_guidance/pdf/DSOPMSeating-120820.pdf [accessed 05.12 2018].

Jacobs, J. (1971). The Rise and Fall of Great American Cities. New York: Vintage Books.

King, D. (2008). Neighborhood and Individual Factors in Activity in Older Adults: Results From the Neighborhood and Senior Health Study. Journal of Aging and Physical Activity, 16 (2), 144-170. doi: 10.3390/ijerph14090960

Klaman, M. (2015). Starość ekspertem od przestrzeni. In Miasto dla wszystkich. Szkice o przestrzeni publicznej w perspektywie starzejacego się spoleczeństwa (pp. 9-11). Warszawa: Towarzystwo Inicjatyw Twórczych ,e”".

Lee, C. \& Moudon, A.V. (2006). Correlates of walking for transportation or recreation purposes. Journal of Physical Activity \& Health, 3, 77-98. doi: 10.1123/jpah.3. s1.s77

Lotvonen, S., Kyngäs, H., Koistinen, P., Bloigu, R. \& Elo, S. (2017). Social Environment of Older People during the First Year in Senior Housing and Its Association with Physical Performance. International Journal of Environmental Research and Public Health, 14 (960). doi: 10.3390/ijerph14090960

Madden, K. (2001). How to Turn a Place Around: A Handbook for Creating Successful Public Spaces. New York NY: Project for Public Spaces.

Main, B. \& Hannah, G. G. (2010). Site Furnishings: A Complete Guide to the Planning, Selection and Use of Landscape Furniture and Amenities. New Jersey NJ: John Wiley \& Sons.

Michael, Y. L., Keast, E. M., Chaudhury, H., Day, K., Mahmood, A. \& Sarte, A. F. I. (2009). Revising the senior walking environmental assessment tool. Preventive Medicine, 48 (3), 247-249. doi:10.1016/ j.ypmed.2008.12.008

Mooney, P. \& Luymes, D. (1999). Mount Pleasant Wellness Walkways. Design study report - Vancouver. Vancouver: Engineering Services.

Newton, R. (2015). Ulice, siedzenie. In Miasto dla wszystkich. Szkice o przestrzeni publicznej $w$ perspektywie starzejacego się społeczeństwa (pp. 52-85). Warszawa: Towarzystwo Inicjatyw Twórczych „„e”.

Olszak, P., Sadowska, N., Skibińska, M. \& Wieczorek, M. (2018). Perspektywa trzecia: seniorzy w przestrzeniach tranzytu. In M. Skibińska, M. Wieczorek (eds.), Usiqdziesz? Co sprawia, że na lawkach (nie) chce się siedzieć (pp. 91-100). Warszawa: Wydawnictwo Uniwersytetu Warszawskiego. 
Prezydent m.st. Warszawy (2013). Program Warszawa Przyjazna Seniorom na lata 2013-2020 (załącznik nr 1 do uchwały Nr LXXII/1870/2013 Rady m.st. Warszawy $\mathrm{z}$ dnia 5 grudnia 2013 r.). Retrieved from: http://senioralna.um.warszawa.pl/dokumenty-strategiczne/programwarszawa-przyjazna-seniorom [accessed 16.11.2018].

Prezydent m.st. Warszawy (2016). Rozwój ruchu pieszego $w$ Warszawie: Standardy projektowania $i$ wykonywania (załącznik nr 1 do Zarządzenia nr 1539/2016 z dnia 12.10.2016). Retrieved from: http://bip.warszawa.pl/ NR/exeres/C757982E-749C-4C54-A0DE-5CAF67CC2A8E,frameless.htm [accessed 16.11.2018].

Skibińska, M. \& Wieczorek, M. (2018). Lawka idealna. In M. Skibińska, M. Wieczorek (eds,), Usiadziesz?
Co sprawia, że na ławkach (nie) chce się siedzieć (p. 101). Warszawa: Wydawnictwo Uniwersytetu Warszawskiego.

Trakul-Masłowska, M. (2015). Miasto dla wszystkich. In Miasto dla wszystkich. Szkice o przestrzeni publicznej w perspektywie starzejacego się społeczeństwa (pp. 7-8). Warszawa: Towarzystwo Inicjatyw Twórczych ,ę".

Whyte, W. H. (1980). The social life of small urban spacer. New York: Project for Public spaces.

World Health Organization [WHO] (2007). Global Age-friendly cities: a guide. Retrieved from: http://www. who.int/ageing/age_friendly_cities_guide/en/[accessed 02.02.2018].

\section{MIEJSCA DO SIEDZENIA DLA SENIORÓW W PRZESTRZENI MIEJSKIEJ. PRZYPADEK WARSZAWSKI}

\section{STRESZCZENIE}

Ławki to meble miejskie, które gwarantują komfort wszystkim użytkownikom, co jest ważne zwłaszcza w kontekście potrzeb starzejących się społeczeństw. Ich lokalizacja, liczba i konstrukcja mają ogromne znaczenie. Niniejszy artykuł opiera się na wynikach projektów badawczych dotyczących ławek miejskich w przestrzeni publicznej Warszawy. Zakres merytoryczny opracowania obejmuje identyfikację bieżących problemów związanych z miejscami do siedzenia na obszarach miejskich oraz związanych z nimi potrzeb osób starszych. Zgodnie z wynikami badań ławki powinny mieć oparcie lub oparcie i podłokietniki, być umieszczone w regularnych odstępach, w pobliżu miejsca zamieszkania i punktów handlowo-usługowych. Niniejszy artykuł stanowi wkład w dyskusję na temat kształtowania przestrzeni publicznej, która jest wygodna dla seniorów.

Słowa kluczowe: miasta przyjazne seniorom, polityka transportu pieszego, przestrzeń publiczna, meble miejskie, ławka miejska, urbanistyka 
